\title{
Pollen substitutes increase honey bee haemolymph protein levels as much as or more than does pollen.
}

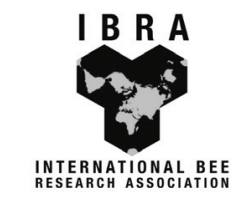

\author{
David De Jong ${ }^{1 *}$, Eduardo Junqueira da Silva², Peter G. Kevan ${ }^{3}$, James L. Atkinson ${ }^{4}$. \\ ${ }^{1}$ Genetics Department. Faculty of Medicine, University of São Paulo, 14 049-900 Ribeirão Preto, SP, Brazil. \\ ${ }^{2}$ Entomology, FFCLRP, University of São Paulo, 14 049-900, Ribeirão Preto, SP, Brazil. \\ ${ }^{3}$ Department of Environmental Biology, University of Guelph, Ontario N1G 2W1, Canada. \\ ${ }^{4}$ Department of Animal and Poultry Sciences, University of Guelph, Ontario N1G 2W1, Canada.
}

Received 21 February 2008, accepted subject to revision 31 March 2008, accepted for publication 4 September 2008.

${ }^{*}$ Corresponding author: Email: ddjong@fmrp.usp.br

\section{Summary}

Adequate substitutes for pollen are necessary for maintaining healthy bee colonies during periods of pollen dearth, but testing them objectively is both time consuming and expensive. We compared two commercial diets with bee collected pollen and acacia pod flour (used by beekeepers in some parts of Brazil) by measuring their effect on haemolymph protein contents of young bees exclusively fed on these diets, which is a fast and inexpensive assay. The commercial diets included a new, non-soy-based, pollen substitute diet (named Feed-Bee ${ }^{\circledR}$ ) and a soy-based diet, named Bee-Pro ${ }^{\circledR}$. The diets were each given in patty form to groups of 100 Africanized honey bees in hoarding cages, maintained and fed from emergence until six days of age. Sucrose, in the form of sugar syrup, was used as a protein free control. Feed-Bee ${ }^{\circledR}$, Bee-Pro ${ }^{\circledR}$, pollen and acacia pod flour diets increased protein titers in the haemolymph by factors of $2.65,2.51,1.76$ and 1.69 , respectively, over protein titers in bees fed only sucrose solution. The bees fed Feed-Bee ${ }^{\circledR}$ and Bee-Pro ${ }^{\circledR}$ had their haemolymph significantly enriched in protein compared to the controls and those fed acacia pod flour and to titers slightly higher than those fed pollen. All four proteinaceous diets were significantly superior to sucrose alone.

\section{Los substitutos del polen incrementan los niveles de proteína en la hemolinfa de la abeja melífera igual o más que el polen.}

\section{Resumen}

Los substitutos del polen son necesarios para mantener saludable a la colonia de abeja durante períodos de escasez del polen, pero en los estudios con estos substitutos suele invertirse mucho tiempo y son costosos. Comparamos dos dietas comerciales con polen y una harina de vainas de Acacia (utilizada por apicultores en algunas regiones de Brasil), midiendo su efecto sobre los contenidos proteínicos de la hemolinfa de abejas jóvenes alimentadas exclusivamente con estas dietas, una prueba rápida y barata. A las dietas comerciales, se le incluyó un nuevo substituto de polen, no basado en soja (conocido comercialmente como Feed-Bee ${ }^{\circledR}$ ) y una dieta a base de soja, conocida como Bee-Pro ${ }^{\circledR}$. Cada dieta se aplicó en forma de tarta a grupos de 100 abejas africanizadas en jaulas de observación, a partir de su emergencia hasta los seis días de edad. La sucrosa en jarabe de azúcar, fue utilizada como dieta control sin proteína. Las dietas con el Feed-Bee ${ }^{\circledR}$, el Bee-Pro ${ }^{\circledR}$, el polen y la harina de vainas de Acacia incrementaron los valores de proteína en la hemolinfa por factores de 2,65, 2,51, 1,76 y 1,69, respectivamente, con respecto a los valores de proteína en las abejas alimentadas solamente con jarabe de sucrosa. Las abejas que fueron alimentadas con Feed-Bee ${ }^{\circledR}$ y Bee-Pro ${ }^{\circledR}$ presentaron en su hemolinfa un significativo enriquecimiento de proteína comparada con las del grupo control y valores ligeramente más altos que aquellas alimentadas con polen. 


\section{Introduction}

Protein plays a major role in the life of honey bees (Amdam and Omholt, 2002) and other insects (House, 1961; Cohen, 2003). Honey bee longevity, brood rearing, and honey production is reduced when protein availability is inadequate (Crailsheim, 1990; Herbert, 2000). Colonies that have no access to pollen, the bees' natural source of protein, have a reduced capacity to rear brood, quickly decline in population, and may eventually die. Protein deficiency also affects the ability of honey bees to resist diseases (Matilla and Otis, 2006); consequently, it is suspected to be an important factor involved in "Colony Collapse Disorder" (Cox-Foster et al., 2007). As pollen is not always available, an alternative protein source is sometimes necessary to ensure bee health and continued colony development, as well as to maintain colony strength for pollination, overwintering, and honey production (Standifer et al., 1980; Goodwin et al., 1994; Herbert, 2000). Various supplementary diets (i.e. those that contain pollen) are advocated and some are commercially available. Pollen is, however, expensive and can transmit disease organisms.

Testing artificial bee diets objectively is difficult. The collection of dietary material by the bees may not mean that it is adequate. During dearth periods, honey bees often collect substances that have consistencies similar to pollen, such as road dust and bird feed, even if they have no nutritional value for the bees. Measuring colony brood production, which is probably the most relevant characteristic, is time consuming, requires many colonies, and needs to be done under controlled conditions to avoid effects of pollen collection from natural sources (Herbert et al., 1985). An alternative technique that allows rapid testing of diets consists of feeding recently emerged adult bees in small hoarding cages for six days and then measuring the protein contents in their haemolymph (Cremonez et al., 1998). Both overall protein levels and concentrations of the key honey bee storage protein, vitellogenin, are increased by nutritionally superior protein diets. Bee bread (pollen stored in brood comb that has been fermented) gives the highest protein levels with this diet evaluation technique (Herbert and Shimanuki, 1978; Gilliam, 1997), especially when made from fresh pollen (Pernal and Currie, 2000; Gregory, 2006).

Various alternative bee diets have been found to be nutritionally poor or unpalatable and most are not well tested (Herbert, 2000). Commercially available pollen substitutes (i.e. those that do not contain any pollen) have been better studied, but beekeepers have experienced mixed results with their use. Those based on soy flour have been reported to be inferior (Pham-Delegue et al., 2000; Manning et al., 2007; Saffari, 2008); so a new non-soy-based diet, called Feed-Bee ${ }^{\circledR}$, was developed (Saffari et al., 2004) (the recipes for Feed-Bee ${ }^{\circledR}$ and Bee-Pro ${ }^{\circledR}$, the non-soy-based pollen substitute we used, are proprietary).

Although consumption rates of pollen substitutes may prove their palatability, only through nutritional tests can their worth be evaluated. The method of investigating the efficiency of a protein source by detecting the level of protein in the haemolymph of worker bees fed on pollen and pollen substitute diets provides a means to determine the actual benefit that the bees obtain from pollen substitutes or supplements (Bitondi and Simões, 1996; Cremonez et al., 1998; Szymas and Jedruszuk, 2003). Thus, the objective of our study was to determine the efficiency of Feed-Bee ${ }^{\circledR}$, pollen, Bee-Pro ${ }^{\circledR}$, and also acacia pod flour (Prosopis juliflora, which is commonly advocated by Brazilian beekeepers for feeding to honey bees, Perreira et al., 2006) as protein supplements for honey bees by measuring total protein in the haemolymph of caged honey bees fed these diets.

\section{Materials and methods}

Groups of 100 newly emerged Africanized honey bees, collected from three different colonies in an apiary in Ribeirão Preto, SP, Brazil, were mixed and placed into hoarding cages (Kulincevic and Rothenbuhler, 1973; Mardan and Kevan, 2002). The cages with bees were maintained in an incubator, with no light, at $30^{\circ} \mathrm{C}$ and about $70 \%$ relative humidity. The bees randomly received one of four proteinaceous diets: pollen; Feed-Bee ${ }^{\circledR}$; Bee-Pro ${ }^{\circledR}$; of acacia (Prosopsis juliflora) pod flour. All were administered as a paste and the bees were allowed to feed ad libitum (Cremonez et al., 1998). The acacia pod flour was obtained from a local Brazilian market. Pollen was collected from pollen traps in our university apiary in Ribeirão Preto and was stored at about $-4^{\circ} \mathrm{C}$ in a refrigerator for up to a week, until it was incorporated into the diets. All diets had a similar final consistency and were prepared by mixing one part (by weight) of the proteinaceous powder with two parts of commercial grade finely granulated sucrose, which was ground with a spice grinder to powder consistency. Enough water was added to obtain a paste. Water was also supplied in glass tubes capped with cotton balls.

Approximately $20 \mathrm{~g}$ of each diet was placed in a hoarding cage, in a shallow plastic container and the diets were replaced every two days. A protein free control was provided by feeding a fifth group of bees with $50 \%$ (by weight) sucrose syrup. A trial consisted of five cages, one for each diet and three trials were made, sequentially. Consumption rates were not recorded.

After the newly emerged bees had been fed for six days, five to six bees were removed from each cage and haemolymph was collected from a small incision at the level of the $3^{\text {rd }}$ dorsal tergite, into microcapillary tubes previously washed in a $0.1 \%$ (wt:vol) phenylthiourea solution in water. The protein concentration was determined spectrophotometrically for each bee (Cremonez et al., 1998). The mean haemolymph protein concentrations of the bees fed the various diets were compared by ANOVA and comparisons between the diets were made by Tukey's test (Sigma Stat, 1995). 
Table 1. Crude protein (\%) of the protein sources and mean protein titers $(\mu \mathrm{g} / \mu \mathrm{l}$ haemolymph) of the haemolymph of individual six day old Apis mellifera workers, fed on artificial diets or pollen from day 0 (when the newly-emerged bees were placed in the cages). The haemolymph was collected from five to six bees (analysed individually) from each of three sequential repetitions (cages of 100 bees). The protein contents of the diet materials (before mixing with sucrose to prepare the diet patties) were obtained by analyses made by Industrial Laboratories of Canada Inc. (Feedbee ${ }^{\circledR}$ ), and by the manufacturer (Bee-Pro ${ }^{\circledR}$ ), except for the pollen and acacia pod flour, which were analyzed in Brazil. *Protein titers followed by the same letter are not significantly different from each other (Tukey's test, $a=0.05$ ).

\begin{tabular}{|l|c|c|c|c|}
\hline Diet & $\begin{array}{c}\text { Crude protein } \\
\text { content }\end{array}$ & $\begin{array}{c}\text { Protein titer* } \\
\text { in the haemolymph }\end{array}$ & $\begin{array}{c}\text { Standard deviation of } \\
\text { the protein titers }\end{array}$ & $\begin{array}{c}\text { N (number of } \\
\text { bees tested) }\end{array}$ \\
\hline Feed-Bee ${ }^{\circledR}$ & 36.4 & $9.42^{\mathrm{a}}$ & 4.09 & 18 \\
\hline Bee-Pro $^{\circledR}$ & 29.9 & $8.95^{\mathrm{abc}}$ & 3.51 & 16 \\
\hline Pollen & 20 & $6.26^{\mathrm{bc}}$ & 2.19 & 17 \\
\hline Acacia pod flour & 22 & $6.00^{\mathrm{c}}$ & 2.67 & 15 \\
\hline Sucrose & 0 & $3.56^{\mathrm{d}}$ & 1.62 & 17 \\
\hline
\end{tabular}

\section{Results}

The titers of protein in the haemolymph $(\mu \mathrm{g} / \mu \mathrm{l})$ of the caged honey bees varied significantly among the diet groups $(P<0.01$, ANOVA, Table 1). Feed-Bee ${ }^{\circledR}$ gave the highest protein levels, but it was not significantly superior to the other commercial diet, Bee-Pro ${ }^{\circledR}$.

However, Feed-Bee ${ }^{\circledR}$ performed significantly better than pollen, acacia pod flour and sucrose, while Bee-Pro ${ }^{\circledR}$ was significantly superior to acacia pod flour and sucrose, but not to pollen. All of the proteinaceous diets were superior to sucrose syrup in their ability to elevate the protein content of bee haemolymph.

\section{Discussion}

Both Feed-Bee ${ }^{\circledR}$ and Bee-Pro ${ }^{\circledR}$ out performed pollen (Table 1), giving 2.65 and 2.51 times more protein in the bee haemolymph, respectively, than the sucrose controls, while the increase obtained with pollen was 1.76. This may seems a surprising result, but although pollen is the natural protein source for honey bees, they normally consume it after it has been fermented, in the form of "bee bread" (Herbert and Shimanuki, 1978). Bee bread is superior to bee collected pollen when haemolymph protein values of bees fed on these materials are compared (Cremonez et al., 1998). Though pollen is rich in protein (Roulston and Cane, 2000), it is apparently not all fully available until it has been processed by the bacteria in bee bread (Herbert and Shimanuki, 1978; Gilliam, 1997). We also have no information on the plant origins of the pollen we used; this factor influences the nutritional value of pollen (Barbier, 1970; Baker and Baker, 1983; Pernal and Currie, 2000; Gregory, 2006). The acacia pod flour gave nearly the same protein titers as did the bee-collected pollen (1.69 times the protein found in sucrose fed bees), indicating that this local pollen substitute has some value for honey bees. All four protein sources originally contained at least $20 \%$ crude protein (Table 1 ), before being mixed with sucrose and water. The acacia pod flour we tested contained about $20 \%$ protein, similar to the levels found in pollen, but can vary from $8 \%$ to $40 \%$ crude protein, depending on the fraction of seeds included when it is produced (Perriera et al., 2006). Gregory (2006) reported similarly high levels of haemolymph proteins (ca. $30 \mu \mathrm{g} / \mathrm{ml}$ ) in both Africanized and European honey bees at Weslaco, Texas, USA fed pollen and Feed-Bee ${ }^{\circledR}$, but lower levels in those fed Bee Pro ${ }^{\circledR}$. Amdam and Omholt (2002) reported much higher amounts of vitellogenin in haemolymph than did Gregory (2006) and what we found in the present study. Their results may reflect the temperate adaptations of the race of honey bees they studied, the time of year of their studies, and the requirements for storage proteins in northern temperate zone honey bees as they prepare physiologically for winter. Our study was of tropically adapted Africanized honey bees. Queenless groups of worker honey bees in hoarding cages might moreover be expected to divert protein ingested into ovarian development.

Overall, both Feed-Bee ${ }^{\circledR}$ and Bee-Pro ${ }^{\circledR}$ were superior, the former statistically so, to fresh bee collected pollen and therefore are confirmed to be adequate alternatives for feeding bees. The laboratory trials measuring haemolymph protein in small groups of caged bees successfully paralleled experience with colonies in the field and also demonstrated that modern pollen substitutes can be superior to, or as good as, bee collected pollen, with the added advantages of lower cost and no risk of spreading bee diseases. This protein substitute evaluation technique (Cremonez et al., 1998) also provides a means of determining whether locally available protein materials such as acacia pod flour are good candidates for the development of efficient and inexpensive bee diets.

\section{Acknowledgements}

We are grateful to Adelino Penatti, Natalia Furlan Miranda, Paul Kelly, Michael Adjaloo, Ali Toosi, Jeff Boone and Mohammad Araghi for their practical and technical help. CNPq and FAPESP provided funding. We thank Mann Lake Ltd., Hackensack, MN, USA for the supply of Bee-Pro ${ }^{\circledR}$, and Grain Process Enterprises Ltd., Toronto, ON, Canada for supplying the Feed-Bee ${ }^{\circledR}$. 


\section{References}

AMDAM, G V; OMHOLT, S W (2002) The regulatory anatomy of honey bee lifespan. Journal of Theoretical Biology 216: 209-228.

BAKER, H G; BAKER, I (1983) Some evolutionary and taxonomic implications of variation in the chemical reserves of pollen. In: Mulcahy, D L; Ottaviano, E (Eds), Pollen: Biology and Implications for Plant Breeding. Elsevier, NY. pp. 43-52.

BARBIER, M (1970) Chemistry and biochemistry of pollen. Progressive Phytochemistry 2: 1-34.

BITONDI, M M G; SIMÕES, Z L P (1996) The relationship between level of pollen in the diet, vitellogenin and juvenile hormone titres in Africanized Apis mellifera workers. Journal of Apicultural Research 35: 27-36.

COHEN, A C (2003) Insect Diets: Science and Technology. CRC Press; Boca Raton, USA. 324 pp.

COX-FOSTER, D L; CONLAN, S; HOLMES, E C; PALACIOS, G; EVANS J D; MORAN, N A; QUAN, P L; BRIESE, T; HORNIG, M; GEISER, D M; MARTINSON, V; VAN ENGELSDORP, D; KALKSTEIN, A L; DRYSDALE, A; HUI, J; ZHAI, J H; CUI, L W; HUTCHISON, S K; SIMONS, J F; EGHOLM, M; PETTIS, J S; LIPKIN, W I (2007) A metagenomic survey of microbes in honey bee colony collapse disorder. Science 318 (5848): 283-287.

CRAILSHEIM, K (1990) The protein balance of the honey bee worker. Apidologie 21: 417-430.

CREMONEZ, T M; DE JONG, D; BITONDI, M G (1998) Quantification of haemolymph proteins as a fast method for testing protein diets for honey bees (Hymenoptera: Apidae). Journal of Economic Entomology 91: 1284-1289

GILLIAM, M (1997) Identification and roles of non-pathogenic microflora associated with honey bees. FEMS Microbiology Letters 155 (1): 1-10.

GOODWIN, R M; TEN HOUTEN, A; PERRY, J H (1994) Effect of feeding pollen substitutes to honey bee colonies used for kiwifruit pollination and honey production. New Zealand Journal of Crop and Horticultural Science 22: 459-462.

GREGORY, P G (2006) Protein diets and their effects on worker weight, longevity, consumption and haemolymph protein levels of Apis mellifera. Proceedings of the American Bee Research Conference, 2006. http://www.ars.usda.gov/SP2Userfiles/ Place/64133000/PDFFiles/427-ABJ\%20146.pdf

HERBERT, E W JR. (2000) Honey bee nutrition. In: Graham, J (Ed.). The hive and the honey bee. Dadant and Co.; Hamilton, IL., USA. pp. 197-224.

HERBERT, E W JR.; SHIMANUKI, H (1978) Chemical composition and nutritive value of bee collected and bee stored pollen. Apidologie 9: 33-40.

HERBERT, E W JR.; VANDERSLICE, J T; HIGGS, D J (1985) Effect of dietary vitamin $\mathrm{C}$ levels on the rate of brood production of freeflying and confined colonies of honey bees. Apidologie 16: 385-394.
HOUSE, H L (1961) Insect nutrition. Annual Review of Entomology 6: 13-26.

KULINCEVIC, J M; ROTHENBUHLER, W C (1973) Laboratory and field measurements of hoarding behaviour in the honey bee (Apis mellifera L.). Journal of Apicultural Research 12: 179-182.

MANNING, R; RUTKAY, A; EATON, L; DELL, B (2007) Lipid enhanced pollen and lipid reduced flour diets and their effect on the longevity of honey bees (Apis mellifera L.). Australian Journal of Entomology 46: 251-257.

MARDAN, M; KEVAN, P G (2002) Critical temperatures for survival of brood and adult workers of the giant honey bee, Apis dorsata (Hymenoptera: Apidae). Apidologie 33: 295-301.

MATTILA, H R; OTIS, G W (2006) Effects of pollen availability and Nosema infection during the spring on division of labour and survival of worker honey bees (Hymenoptera : Apidae). Environmental Entomology 35: 708-717.

MORSE, R A (1975). Bees and beekeeping. Cornell University Press; Ithaca, NY, USA.

PERREIRA, F D M; FREITAS, B M; VIEIRA NETO, J M; LOPES, M T R; BARBOSA, A L; CAMARGO, R C R (2006) Development of honey bee colonies under protein diets. Pesquisa Agropecuaria Brasileira 41: 1-7.

PERNAL, S F; CURRIE, R W (2000) Pollen quality of fresh and 1-yearold single pollen diets for honey bees (Apis mellifera L.). Apidologie 31: 387-409.

PHAM-DELEGUE, M H; GIRARD, C; LE METAYER, M; PICARD-NIZOU, A L; HENNEQUET, C; PONS, O; JOUANIN, L (2000) Long term effects of soybean protease inhibitors on digestive enzymes, survival and learning abilities of honey bees. Entomologia Experimentalis et Applicata 95: 21-29.

ROULSTON, T H; CANE, J H (2000) Pollen nutritional content and digestibility for animals. Plant Systematics and Evolution 222: 187-209.

SAFFARI, A M (2008) Effects of feeding honey bees with pollen substitutes and natural pollen on brood rearing, population, and honey production. MSc dissertation, University of Guelph, ON, Canada.

SAFFARI, A M; KEVAN, P G; ATKINSON, J L (2004) A promising pollen substitute. American Bee Journal 144: 230-231.

SIGMA STAT (1995) Stigma Stat user's manual, version 2.0. Jandel Scientific; San Rafael, CA, USA.

STANDIFER, L N; MCCAUGHEY, W F; DIXON, S E; GILLIAM, M; LOPER, M (1980) Biochemistry and microbiology of pollen collected by honey bees (Apis mellifera L.) from almond, Prunus dulcis. II Protein, amino acids and enzymes. Apidologie 11: $163-172$.

SZYMAS, B; JEDRUSZUK, A (2003) The influence of different diets on haemocytes of adult worker honey bees, Apis mellifera. Apidologie 34: 97-102. 